\title{
Information and Communication Technology and Students with Disabilities
}

\author{
Luan Bekteshi \\ Faculty of Economy, University of Elbasan "Aleksandër Xhuvani" \\ Email: luanbekteshi@yahoo.com
}

\section{Doi:10.5901/mjss.2015.v6n4s3p494}

\begin{abstract}
The purpose of this research study was to identify the problems encountered by persons with physical disabilities to attend fulltime studies at the University "Alexander Xhuvani" Elbasan. In addition, it serves to highlight the obstacles in the university environment and to provide adequate information for decision-makers at the university in order for them to be able to recognize such barriers and to carefully consider and plan the inclusion of individuals with physical disabilities in university. Subject for this study were a group of 22 students with physical disabilities, 14 (fourteen) of whom were male and 8 (eight) were female. All these students who were contacted directly have identified difficulties in benefiting applications in the information system of the university, e-learning, web-site navigability, and downloading various documents from the system etc. This paper also gives some suggestions about improvements that should be made to the information system in the university, in order to be used efficiently by persons with disabilities, academically as well as administratively.
\end{abstract}

Keywords: Disabled student, information system, information communication technology, e-learning, education, university, .

\section{Introduction}

Over the past decade, higher education in Albania is facing numerous transformations that have made it possible at the same time by increasing the number of people who want to attend the auditors of universities for their formation.

Challenges imposed by global markets and competition have become important factors to expand higher education in Albania. Universities have become in this way a very important factor in the formation of qualified human resources, the social and economic life as a whole.

There is a special group of society that attends university which we call them people with physical disabilities.

For many years, the legislation of many countries in the world as well as in Albania has been paying attention to the education of these groups with the aim of creating conditions in order for them to pursue their education equally like all the other students.

The increased use of Information and Communication Technology (hereinafter: ICT) in many sectors of society has made it possible to perform processes which previously were not done by this category of individuals.

With the use of the ICT, people with physical disabilities that cannot use their hands to communicate or write are now able to communicate by using special software's as Fichten, Asuncion, Barite etc.

The ones that do not listen may use the "chat Programs" for communication, and the ones that do not see (blind) are able to communicate by using a technology called "text-to-speech".

The use of ICT simultaneously represents significant aid factor and a potential factor of difficulties (barriers) for persons with disabilities, certainly for those who attend college or/univerity and use their technology.

Even in the University of "Alexander Xhuvani" the use of ICT in education and e-learning has influenced positively by assisting the people with disabilities in order to enhance their ability and increase their independence in the process of education.

However, just how effective is the use of ICT and information systems at the university by creating optimal conditions for higher education enrollment by people with physical disabilities?

How the use of ICT could promote equal opportunities for all students?

\section{Literature Review}

Today's society lives in the era of the Internet and ICT. Developing very fast pace of telecommunications and ICT in parallel with economic globalization have made the transformation of social relations, culture and education. Over the last decade, ICT has become an important factor in the revolution of universities as from the administrative aspects as well as 
academically which has affected the main activities in the university.

Apparently, the information system is a tool that serves for distribution and better management of information for both the university's academics /administrative staff, as well as for students in the implementation of administrative and academic processes.

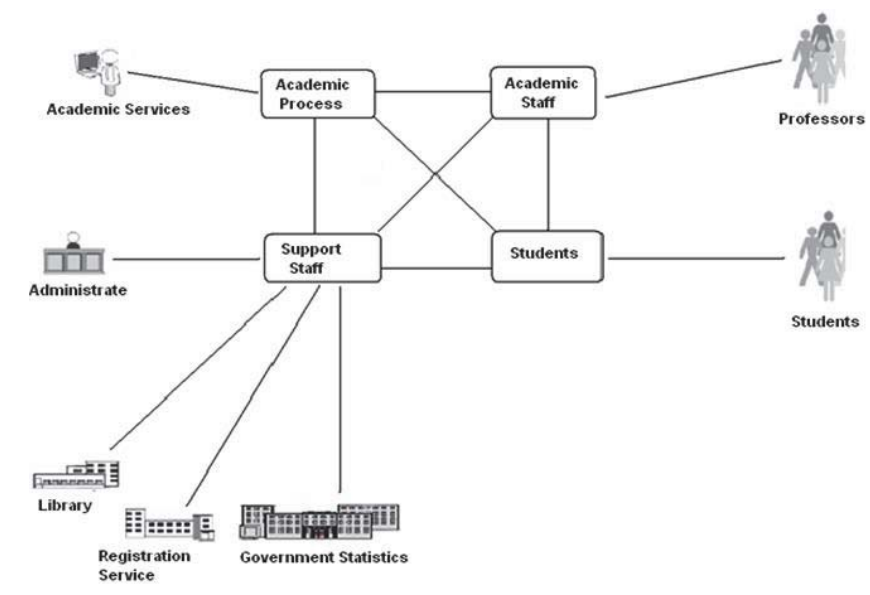

Therefore, ICT and the information systems have become indispensable tools in the university.

According to Jagar and Lokman (1999) in a paper to the European Conference on Education Research proposed these functions of ICT in education:

- Learning about ICT so that students can use ICT in education, future occupation and social life.

- Use ICT as an assisting tool e.g. making assignments, collecting data and documentation, communicating and conducting research.

- Use ICT as a medium for teaching and learning, as a tool through which teachers can teach and learners can learn.

- Use ICT to organize and manage universities.

Over the past decades the social, economic, and technological changes are making education and training more crucial than ever. Nevertheless, educational systems to different degrees worldwide are struggling to afford educational opportunities for all, to provide their graduates with the necessary knowledge and skills for evolving marketplaces and living environments, and to prepare citizens for lifelong learning.

In this global challenge of education, the governments have strongly prioritized education of individuals with physical disabilities. Even this stratum of society has the right to education at all levels of the education system.

Regarding the general education, the CRPD (United Nations Convention on the Rights of Persons with Disabilities) (2006), states that, among other requirements, Government Parties shall ensure that:

- people with disabilities are not excluded from the general education system;

- people with disabilities receive the support required to facilitate their effective education;

- people with disabilities learn life and social development skills to facilitate their full and equal participation in education;

- the learning of Braille, alternative script, augmentative and alternative modes, means and formats of communication and orientation and mobility skills, and facilitating peer support and mentoring.

The uses of ICT and information systems in universities have allowed individuals with disabilities to do things that were difficult or impossible for them to do in the past.

Abrami et al. (2006), who recently showed how important e-learning initiatives are in Canadian postsecondary education, noted that "we know very little about the e-learning needs and concerns of students with disabilities.

Additionally, Anderson (2006) underlines that, in the field of education, "while.... technologies are beneficial and have shown to help with educational tasks, their design and usability are an issue".

According Cooper (2004), "Enabling" or "assistive" technologies are one obvious area in which ICT can support students with physical or sensory disabilities. 
Even though, the ICT and information systems are considered powerful tools to foster learning and the same time they disadvantage or exclude groups including here the disabled students [....], disabled people face serious problems in accessing computing devices". Stephanidis \& Savidis (2001)

ICT creates a number of problems in education such as: digital equity, the need for a relatively expense addition to the school's infrastructure, and other issues that come up in order to provide appropriate ICT education. ICT in education creates problems of how to deal with potential changes in curriculum content, instructional processes, and assessments in a manner that leads students in getting a better education.

Nevertheless, technological development can enable people with disabilities to improve their quality of life. Technology can help to create a better educational environment for all, for students and professors. In the field of education, the massive use of new technologies has provided new opportunities for the education of individuals with physical disabilities affecting the growth of independence, integration and equal opportunities to this group of society.

\section{Method}

\subsection{Participants}

Participants in this study were 22 students with physical disabilities at the University of Elbasan "Alexander Xhuvani", of which 14 students were men and 8 students were female. Students were users of the ICT and information system and studied in various faculties within the university in levels, bachelor and masters.

The University of "Aleksander Xhuvani" in Elbasan is one of the most important educational and research institutions in Albania. This institution has made successful efforts and been confirmed as one of the most serious educational institutions in Albania by expanding infrastructure, enhancing the quality of curriculum, teaching and researching process.

The University has a capacity of :

- 1204 students

- 256 academic staff

- 302 external academics

- 92 support staff

It is organized in three forms of study: full time, part time and distance learning in the following levels:

- Bachelor

- Professional Master

- Master of Sciences

- Ph.D.

In the total of students who attend the university, 24 students are with physical disabilities.

The table below shows that the largest number of students with disabilities belongs to the group of persons who have difficulty in expressing fluently and then those with difficulties in the use of hands and who have difficulties in hearing.

\begin{tabular}{|l|c|c|}
\hline Disability & Number of students & Percentage \\
\hline Difficulties in the use of hands or arms & 5 & $22.7 \%$ \\
\hline Difficulty in hearing & 5 & $22.7 \%$ \\
\hline Difficulties in communication (fluent expression) & 8 & $36.4 \%$ \\
\hline Difficulty in sight (visual uncertainties) & 4 & $18.2 \%$ \\
\hline
\end{tabular}

\subsection{Procedures}

This paper describes a qualitative study of the university's environment were ICT and information system is used, the benefits that students with physical disabilities attain from using them and the obstacles that they encounter.

Method of data collection in this study was done by interviewing participants' face-to face for 35 to 40 minutes with each. Depending on the degree of disability of some students these interviews lasted less than 30 minutes and for others more than 45 minutes.

Student that participated to this research were addressed the following questions:

- Age

- Hometown 
- Residence

- The type of physical disability

- Profile of high school in which they studied

- Familiarization with the use of ICT

- Use of e-learning platform in the process of their education

- Use of actual application offered by information system for administrative processes.

- Use of information system applications in the process of testing and assessment of student knowledge.

- The functionality of the technology used by students with disabilities to utilize the services of information system in the academic process and at the administrative level.

- The most important benefits they receive from the use of information system

- The main difficulties faced by students with disabilities from the use of information system.

- Improvements and demanding solutions that these students had to be taken into consideration by the university's administration in order to make it more useable for them.

\section{Results}

The results obtained from processing the answers given by these students for the realization of this work had no dependence on their gender. Additionally they were not associated with any demographic factors such as character birthplace, residence and high school profile from which they had attended.

Familiarity with previous use of ICT was a factor which affected the quality of the answers given by students in connection with the use of the e-learning platform, the use of information system applications in administrative processes, in the process of testing as well as with the functionality of the technology implemented.

In the data collected from the interviews a number of necessary requests were identified requiring a more efficient use of information system, e-learning platform, and ICT.

Depending on the type of disability that students had, different approaches to the use of information communication technology were recognized. Thus, students with difficulties in the use of hands and arms had more difficulties in the use of technology and information system, students who have difficulties in communication, hearing and vision have a better approach in the use of technology and system information but at the same time also had their requests to improve the functionality of the system.

Repeatedly, the interviewees emphasized the fact that a major problem for them was the available equipment's which were not suitable enough to help them to use fully the services provided by the university's information system. Students were often frustrated because they were not able to download various materials from the system.

From the interviews with students with difficulties in the use of hands was emphasized that they had more difficulties to use the technology because it was unsuitable for them, since the physical configuration information system was arranged by taking into consideration the requirements of normal students. In these interviews was highlighted the need to create suitable positions, from which this category of students will realize access in the system.

And by interviewing students with visual disabilities it resulted that these students had problems with equipment outflows, mainly with monitors because their inability of seeing clearly and the small monitors which did not allowed them full satisfaction of using the information system.

In spite of the accumulated results, to be appreciated was the fact that all students with disabilities who were interviewed were well aware of the benefits that can be obtained from the use of the ICT and the information system on campus by means of the realization of administrative duties, as well as in the process of learning and testing their knowledge. But on the other hand, students had different approaches in respect of benefits that may apply to the use of ICT and information system implemented specifically in the university.

The following table gives a complete structure of students' approach on the benefits that they really take from the information system in the university.

\begin{tabular}{|l|c|c|}
\hline Benefit & Number of students & Percentage \\
\hline Assistive in the process of learning by students & 10 & $45.5 \%$ \\
\hline Assistive in attendance of on-line courses by students & 6 & $27.3 \%$ \\
\hline Assistive in providing materials through the Web by students & 8 & $36.4 \%$ \\
\hline Assisting utilization of appropriate technology by students & 5 & $22.7 \%$ \\
\hline Assisting in the use of technology in the process of testing of student knowledge. & 2 & $9.1 \%$ \\
\hline Other benefits & 9 & $40.9 \%$ \\
\hline
\end{tabular}




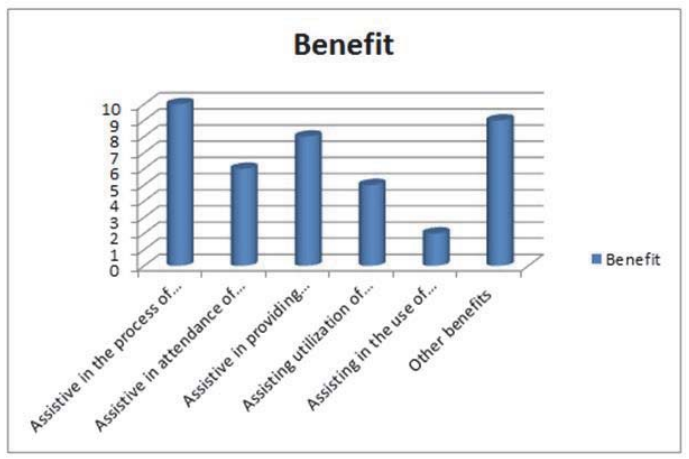

Even though the students interviewed were very clear about the benefits that the use of ICT provides, the reality of its use in the university had made them pessimistic on the use of ICT in the future.

On the other hand, all students stressed out the lack of curriculum, teaching and testing methods for students with physical disabilities.

\section{Recomandations}

From interviews conducted with students with physical disabilities, a number of problems associated with the use of ICT and information system were identified. A considerable part of the problems were related to the operational side of ICT which cannot be fully used from these students. For solving the problems demonstrated in this paper simultaneously some recommendations are provided.

There is an immediate need to raise the awareness to students and professors for the use of ICT in the process of education for students with physical disabilities.

There is a need to develop curriculum and teaching methods for students with physical disabilities.

At the same time, it is recommended to find solutions and develop appropriate strategies for customizing the ICT and ensuring appropriate technology for students with physical disabilities.

In order to make possible the elimination of this problematic it is recommended to build special posts for students with disabilities equipped with special software and hardware as follows:
Keybords: Big keyboards, multicolored keys, keyguard, non standart keyboards including one handed are more available, on-screen keyboard, etc.
Mouse: Instead of a standart mouse, disabled student mus use a rollerball, a tuuchpad or a joystick.
Screens: Use of bigger screens, to help students with visual disability, touch screens for students who cannot mange a mouse for physical disability.
Alternative Input: Speech to text softwares which permits text to be input by speaking into a headset.
Speech Output: Many sofwares are available for speech feedback useful to students or other users with disabilies.

Another problematic raised is related to the process of testing students' knowledge, for the ones with physical disabilities it is necessary to provide appropriate testing formats in accordance with the type of disability and to also have the right for extra-time during the testing process.

The use of mobile technology for learning by students with physical disabilities is another opportunity to access the learning program inside and outside their auditors.

\section{References}

Adam, T. Rigoni, A. And Tatnali, A, (2006), Designing and Implementing Curriculum for Students with Special Needs: A acse Study of a Thinking Curriculum. Journal of Business Systems, Governance and Ethics

Anderson, P. (2007), "The future of Human-Computer interaction" in Emerging Technologies for learning. BECTA 2007, http://becta.org. uk/corporate/documents/Emerging_Technologies

Burgstahler, S, Corrigan, B and McCarte, J. (2005), Steps toward Making Distance Learning Accessible to Students and Instructors with Disabilities. Information Technology and Disabilities

Cochran, P. S. (2000), Technology for Individuals with speech and language diorders. In Technology and expceptional individuals. 3rd 


\section{ed. J.D. Lindsay, ed Austin, TX:Pro-Ed}

Cooper, M. (2004), Extending access using ICT: issues and prospects. In Mediating science learning through information and communication technology, ed. Holliman, R. And Scanlon, E. London

Donegan, M. (2000), "Computers and Inclusion - Factors for Success" ACE Centre / Becta publication,

Goodman, D. Tiene \& P. Luft, (2002) "Adoption of assistive technology for computer access among college students with disabilities. Disability and Rehabilitation

Jenkis, J. Plous, C. \& Jewell, M. (1990), "Special Education and the regular education initiative: Basic assumption". Experimental Children

Kaye, H. S. (2000), "Computer and Internet Use Among People with Diasbilities, Disability Satistic Report, Washington DC:US Department of Education

Lewis, S. (2003), Enhancing teaching and learning of science through use of ICT: methods and materials. School Science Review

Rahamim, L. (1993)."Access to words and images: using information technology to support the learning of students with physical disabilities" National Council for Educational Technology (NECT publisher)

Schmidt, M. and Cagran, B. (2008), "Self-concept of students in inclusive settings". International Journal of Special Education, Vol 23, No.1

Stephanidis, C. And Savidis, A. (2001), "Universal Acces in the Information Society: Methods, Tools, and Interaction Technologies", Universal Access in the Information Society, Springer

Westbrook, L.(2010), "Understanding faculty information needs in a special education setting: method and result of a community analysis". Knowledge Quest. Vol 30, No. 2,

UNESCO, (2005), Guidelines for inclusion:ensuring access to education for all. Paris: UNESCO

UNESCO, (2010), "Education for All Global Monitoring Report", 2010. Available at http://www.unesco.org/new/en/education/themes/ leading-the-internationalagenda/efareport/reports/2010-marginalization/

UNESCO, (2011). "ICTs in education for people with disabilities. Review of innovative practice"

United Nations, (2006), "Convention on the Rights of Persons with Disabilities, 